\title{
First total synthesis of (+)-epogymnolactam, a novel autophagy inducer
}

\author{
Yuji Okado, Kengo Shigetomi, Shinya Mitsuhashi and Makoto Ubukata
}

A novel autophagy inducer, (+)-epogymnolactam (1), was first synthesized from cis-4-benzyloxy-2-butene-1-ol (2) in eight steps. A reliable preparation of optically pure epoxy alcohol (+)-3 from monobenzyl derivative (2) was established by a tandem strategy, Sharpless epoxidation/lipase kinetic resolution.

The Journal of Antibiotics (2015) 68, 721-724; doi:10.1038/ja.2015.63; published online 27 May 2015

\section{INTRODUCTION}

(+)-Epogymnolactam (1) was discovered as a novel autophagy inducer from a mycelial culture of Gymnopus sp. in our laboratory (Figure 1). ${ }^{1}$ Autophagy is one of the major intracellular degradation systems in eukaryotic cells, eliminating damaged organelles and protein aggregates to maintain cytoplasmic homeostasis. This degradation pathway has important roles in such diseases as cancer, neurodegenerative and infectious diseases. Thus, the application of autophagy inducer would help to understand the regulatory roles of autophagy in human diseases, and provide insight into the development of therapeutic agents that target autophagy. ${ }^{2-5}$ As an example of the effort for the development of autophagy-inducing drug, a peptide has been reported to have benefits in the clearance of a model polyglutamine expansion protein aggregates in $\mathrm{HeLa} / \mathrm{htt} 103 \mathrm{Q}$ cells, inhibition of intracellular survival of the bacterium, Listeria monocytogenes, inhibition of HIV-1 replication in human monocyte-derived macrophages and a reduction in the mortality of neonatal mice infected by chikungunya virus and West Nile virus. ${ }^{6}$ Although researchers have identified different types of autophagy inducers, for example, rapamycin, an inhibitor of mTORC $1 ;^{7}$ lithium L-690330, an inhibitor of IMPase; ${ }^{8}$ verapamil, $\mathrm{Ca}^{2+}$ channel blocker; 9 resveratrol, activator of sirtuin 1 and inhibitor of S6 kinase; ${ }^{10}$ clonidine, an imidazole-1 receptor agonist; ${ }^{9}$ minoxidil, a $\mathrm{K}^{+}$ATP channel opener; ${ }^{9}$ spermidine, endogenous anti-aging mediator, ${ }^{11} \alpha$-ketoglutarate, inhibitor of ATP synthase ${ }^{12}$ and so on, none of these compounds is similar to $\mathbf{1}$ in chemical structure.

The structure of $\mathbf{1}$ deduced by spectroscopic analysis resembled to (+)-cerulenin, ${ }^{13}$ a potent inhibitor of fatty acid synthesis, ${ }^{14-16}$ and the absolute structure of $\mathbf{1}$ was assigned by the comparison of its specific rotation with that of $(+)$-cerulenin. ${ }^{1}$ To evaluate chemical and biological properties of $\mathbf{1}$ more precisely, we needed to synthesize enough amount of $\mathbf{1}$ in enantiomerically pure form. Here we report the first total synthesis, and thus structural confirmation of 1 by direct comparison of the natural product with the synthetic compound.

\section{MATERIALS AND METHODS}

Chemicals of the highest commercial purity were used without further purification. Thin-layer and silica gel column chromatography were performed by using Merck Silica Gel $60 \mathrm{~F}_{254}$ (Merck, Frankfurt, Germany) and Kanto Chemical Co. Silica Gel $60 \mathrm{~N}$ (spherical, neutral; Kanto Chemical Co., Tokyo, Japan), respectively. A DAICEL Chiralpak AD-H column $(\varphi 0.64 \times 25$ $\mathrm{cm}^{2}$; DAICEL, Osaka, Japan) and a Waters 600 System (Waters, Milford, MA, USA) were used for chiral HPLC. ${ }^{1} \mathrm{H}$ and ${ }^{13} \mathrm{C}$ NMR spectra were recorded using a JEOL JNM EX-270 FT-NMR (JEOL, Tokyo, Japan), and HSQC and HMBC spectra were measured with a Bruker AMX-500 (Bruker, Billerica, MA, USA). Mass spectra were acquired with FI modes using a JMS-T100GCV (JEOL,). ESI-MS spectra of (+)-1 were recorded on a LTQ Orbitrap XL (Thermo Scientific, Waltham, MA, USA). Optical rotations were determined on a JASCO P-2000 (JASCO, Tokyo, Japan).

\section{(2R,3S)-4-Benzyloxy-2,3-epoxybutane-1-ol (3)}

To a stirred suspension of activated $4 \AA$ molecular sieves $(2.29 \mathrm{~g})$ in dry $\mathrm{CH}_{2} \mathrm{Cl}_{2}$ $(190 \mathrm{ml}), \quad \mathrm{Ti}\left(\mathrm{O}^{i} \mathrm{Pr}\right)_{4}(7.20 \mathrm{ml}, 24.1 \mathrm{mmol})$ and $\mathrm{D}$-(-)-diisopropyl tartrate (DIPT) $(5.03 \mathrm{ml}, 24.1 \mathrm{mmol})$ were sequentially added under argon at $-25^{\circ} \mathrm{C}$. After stirring for $30 \mathrm{~min}, 2(4.0 \mathrm{~g}, 22.5 \mathrm{mmol})$ in dry $\mathrm{CH}_{2} \mathrm{Cl}_{2}$ (34 ml) was slowly added over $90 \mathrm{~min}$ and the reaction mixture was continually stirred for another $90 \mathrm{~min}$ at $-25^{\circ} \mathrm{C}$. To the solution was added dropwise a nonane solution of $t$-BuOOH $(5.5 \mathrm{M}, 8.8 \mathrm{ml})$ and the solution was stirred for 3 days at $-20^{\circ} \mathrm{C}$. After warming to room temperature (RT), the mixture was diluted with saturated (sat.) aqueous $\mathrm{Na}_{2} \mathrm{~S}_{2} \mathrm{O}_{3}(40 \mathrm{ml})$. The resultant solution was stirred for $2 \mathrm{~h}$ and then filtrated. The filtrate was extracted with $\mathrm{Et}_{2} \mathrm{O}$ and the organic layer was washed with water, dried over $\mathrm{Na}_{2} \mathrm{SO}_{4}$, concentrated and purified by silica gel column chromatography (EtOAc/hexane $=1: 2$ ) to afford epoxy alcohol 3 $(3.26 \mathrm{~g}, 75 \%)$ as a colorless oil. The enantiomeric excess value was determined by HPLC (DICEL Chiralpak AD-H, $0.46 \times 25 \mathrm{~cm}^{2}$, hexane $/ \mathrm{EtOH}=9: 1$, $\left.0.8 \mathrm{ml} \mathrm{min}^{-1}\right)$.

$$
89 \% \text { ee; }[\alpha]_{\mathrm{D}}^{25}=+23.0\left(c 1.00, \mathrm{CHCl}_{3}\right) .
$$

${ }^{1} \mathrm{H} \mathrm{NMR}\left(270 \mathrm{MHz}, \mathrm{CDCl}_{3}\right): \delta=2.14(1 \mathrm{H}, \mathrm{s},-\mathrm{OH}), 3.19-3.32(2 \mathrm{H}, \mathrm{m}, \mathrm{H}-2$ and $\mathrm{H}-3), 3.62-3.75(4 \mathrm{H}, \mathrm{m}, \mathrm{H}-1$ and $\mathrm{H}-4), 4.51-4.64(2 \mathrm{H}, \mathrm{dd}, J=24.7,11.9$, benzyl), 7.28-7.39 (5H, m, aromatic). 
${ }^{13} \mathrm{C}$ NMR $\left(67.5 \mathrm{MHz}, \mathrm{CDCl}_{3}\right): \delta=54.7(\mathrm{C}-3), 55.6(\mathrm{C}-2), 60.7$ (C-1), 68.0 (C-4), 73.5 (benzyl), 127.9 (aromatic), 128.0 (aromatic), 128.5 (aromatic), 137.4 (aromatic).

Field ionization mass spectrometry (FI-MS): $m / z=194.1[\mathrm{M}]^{+}$.

\section{Kinetic resolution of 3}

To a stirred solution of $\mathbf{3}(1.39 \mathrm{~g}, 7.17 \mathrm{mmol})$ in vinyl acetate $(73.8 \mathrm{ml}), 403 \mathrm{mg}$ of porcine pancreatic lipase (PPL; L3126-25G, Sigma, St Louis, MO, USA) was added at RT. The reaction mixture was stirred for $6 \mathrm{~h}$, filtered with Celite pad to remove PPL and the residue on Celite pad was washed with EtOAc. The combined filtrate and washings were concentrated in vacuo, and the resultant residue was purified by silica gel column chromatography $($ EtOAc/hexane $=$ 1:2) to give $1.07 \mathrm{~g}$ of enantiopure (+)-3 (1.07 g. $77 \%)$.

$$
99 \% \text { ee; }[\alpha]_{\mathrm{D}}^{25}=+24.3\left(c 1.00, \mathrm{CHCl}_{3}\right) .
$$

\section{(2R,3S)-4-Benzyloxy-2,3-epoxy-1-butanal (4)}

To a stirred solution of $3(1.06 \mathrm{~g}, 5.47 \mathrm{mmol})$ in $\mathrm{CH}_{2} \mathrm{Cl}_{2}(64 \mathrm{ml}),(2,2,6,6-$ tetramethylpiperidin-1-yl)oxyl (TEMPO) $(8.54 \mathrm{mg}, 54.7 \mu \mathrm{mol})$ and $0.5 \mathrm{M}$ aqueous $\mathrm{KBr}(1.09 \mathrm{ml})$ were added at $\mathrm{RT}$ and then a mixture of $1.96 \mathrm{M}$ aqueous $\mathrm{NaOCl}(3.35 \mathrm{ml})$ and sat. aqueous $\mathrm{NaHCO}_{3}(3.35 \mathrm{ml})$ were added at $0{ }^{\circ} \mathrm{C}$. After stirring for $4 \mathrm{~h}$ at $0{ }^{\circ} \mathrm{C}$, the reaction mixture was quenched with sat. aqueous $\mathrm{Na}_{2} \mathrm{~S}_{2} \mathrm{O}_{3}$ and extracted with EtOAc. The organic layer was washed with brine, dried over $\mathrm{Na}_{2} \mathrm{SO}_{4}$, concentrated in vacuo and purified by silica gel column chromatography (EtOAc/hexane $=1: 2)$ to afford aldehyde $4(893 \mathrm{mg}$, $85 \%)$ as a colorless oil.

$$
[\alpha]_{\mathrm{D}}^{25}=-111.1\left(c 1.00, \mathrm{CHCl}_{3}\right)
$$

${ }^{1} \mathrm{H}$ NMR $\left(270 \mathrm{MHz}, \mathrm{CDCl}_{3}\right): \delta=3.39-4.43(1 \mathrm{H}, \mathrm{t}, J=4.5, \mathrm{H}-2), 3.47-3.52(1 \mathrm{H}$, q, $J=3.1, \mathrm{H}-3), 3.72-3.86(2 \mathrm{H}, \mathrm{m}, \mathrm{H}-4), 4.55(2 \mathrm{H}, \mathrm{s}$, benzyl), 7.29-7.38 (5H, $\mathrm{m}$, aromatic), 9.42-9.44 $(1 \mathrm{H}, \mathrm{d}, J=3.7, \mathrm{H}-1)$.

${ }^{13} \mathrm{C}$ NMR (67.5 MHz, $\left.\mathrm{CDCl}_{3}\right): \delta=57.3(\mathrm{C}-3), 58.0(\mathrm{C}-2), 66.2(\mathrm{C}-4)$ 73.5 (benzyl), 127.8 (aromatic), 128.0 (aromatic), 128.5 (aromatic), 137.1 (aromatic), 197.6(C-1).

FI-MS: $m / z=192.1[\mathrm{M}]^{+}$.

\section{(2R,3S)-2,3-epoxy-1,4-octandiol (6)}

To a stirred solution of 5 (44.7 $\mathrm{mg}, 0.233 \mathrm{mmol})$ in dry tetrahydrofuran (THF) $(1.0 \mathrm{ml})$, a solution of $n$ - $\mathrm{BuMgCl}$ in THF $(2.0 \mathrm{M}, 129 \mu \mathrm{l})$ was added dropwise

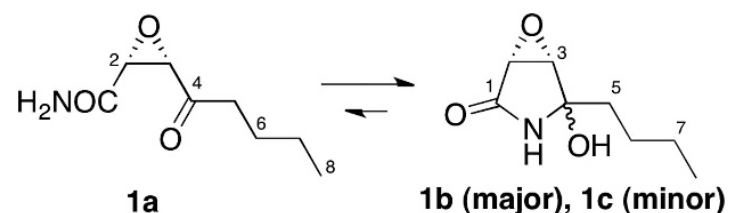

Figure 1 Ring-chain tautomerism of (+)-epogymnolactam (1). under argon at $-78^{\circ} \mathrm{C}$. The reaction mixture was stirred for $1.5 \mathrm{~h}$, and quenched with $\mathrm{MeOH}$. After warming to RT, sat. aqueous $\mathrm{NH}_{4} \mathrm{Cl}$ was added to the solution. The mixture was stirred vigorously and extracted with $\mathrm{Et}_{2} \mathrm{O}$. The organic layer was dried over $\mathrm{Na}_{2} \mathrm{SO}_{4}$, concentrated in vacuo and subjected to silica gel column chromatography $(\mathrm{EtOAc} / \mathrm{hexane}=1: 3)$ to give crude alcohol 5. To a solution of crude $5(50.3 \mathrm{mg})$ in EtOAc $(5.8 \mathrm{ml})$ was added $\mathrm{Pd} / \mathrm{C}$ $(66 \mathrm{mg})$ and the mixture was stirred vigorously under $\mathrm{H}_{2}$ overnight. The resulting solution was filtered, concentrated and purified by silica gel column chromatography $($ EtOAc/hexane $=1: 1)$ to afford a diastereomeric mixture of diol 6 (19.7 mg, 53\% over two steps) as a colorless oil.

$$
[\alpha]_{\mathrm{D}}^{25}=+2.4\left(c 1.00, \mathrm{CHCl}_{3}\right)
$$

${ }^{1} \mathrm{H}$ NMR $\left(270 \mathrm{MHz}, \mathrm{CDCl}_{3}\right): \delta=0.90-0.95(3 \mathrm{H}, \mathrm{m}, \mathrm{H}-8), 1.31-1.77(6 \mathrm{H}, \mathrm{m}$, H-5, H-6 and H-7), 2.93-3.30 (4H, m, H-2, H-3 and $(-\mathrm{OH}) \times 2), 3.55-3.62$ $(1 \mathrm{H}, \mathrm{q}, J=6.7, \mathrm{H}-4), 3.68-3.75(1 \mathrm{H}, \mathrm{dd}, J=12.1,3.3, \mathrm{H}-1), 3.99-4.06(1 \mathrm{H}, \mathrm{dd}$, $J=12.0,2.8, \mathrm{H}-1)$.

${ }^{13} \mathrm{C}$ NMR (67.5 MHz, $\left.\mathrm{CDCl}_{3}\right): \delta=13.9(\mathrm{C}-8), 22.6(\mathrm{C}-7), 27.1(\mathrm{C}-6)$, 35.2 (C-5), 55.6 (C-2), 59.1 (C-3), 60.7 (C-1), 69.7(C-4).

FI-MS: $m / z=161.1[\mathrm{M}+\mathrm{H}]^{+}$.

\section{(1R,5R)-4-Butyl-3,6-dioxabicyclo[3.1.0] hexan-2-one (7)}

To a stirred solution of $\mathbf{6}(22.1 \mathrm{mg}, 138 \mu \mathrm{mol})$ in $\mathrm{CH}_{2} \mathrm{Cl}_{2}(1.8 \mathrm{ml})$, TEMPO $(0.23 \mathrm{mg}, 1.38 \mu \mathrm{mol})$ and $0.5 \mathrm{M}$ aqueous $\mathrm{KBr}(29 \mu \mathrm{l})$ were added at RT, and then a mixture of $1.96 \mathrm{M}$ aqueous $\mathrm{NaOCl}(162 \mu \mathrm{l})$ and sat. aqueous $\mathrm{NaHCO}_{3}(162 \mu \mathrm{l})$ were added at $0{ }^{\circ} \mathrm{C}$. After stirring for $4 \mathrm{~h}$ at $0^{\circ} \mathrm{C}$, the reaction mixture was quenched with sat. aqueous $\mathrm{Na}_{2} \mathrm{~S}_{2} \mathrm{O}_{3}$ and extracted with EtOAc. The organic layer was washed with brine, dried over $\mathrm{Na}_{2} \mathrm{SO}_{4}$, concentrated in vacuo and purified by silica gel column chromatography (EtOAc/hexane $=1: 3)$ to afford $7(78 \%)$, which was separable to major isomer (Rf value: $0.4,14.5 \mathrm{mg}$, $67 \%$ ) and minor isomer ( $\mathrm{Rf}$ value: $0.3,1.7 \mathrm{mg}, 8 \%$ ) as a colorless oil, respectively.

$$
\begin{aligned}
& \text { Majorisomer : }[\alpha]_{\mathrm{D}}^{25}=+48.9\left(\text { c 1.00, } \mathrm{CHCl}_{3}\right) \\
& \text { Minorisomer : }[\alpha]_{\mathrm{D}}^{25}=+37.3\left(\text { c } 0.13, \mathrm{CHCl}_{3}\right)
\end{aligned}
$$

${ }^{1} \mathrm{H}$ NMR $\left(270 \mathrm{MHz}, \mathrm{CDCl}_{3}\right): \delta=0.91-0.96(3 \mathrm{H}, \mathrm{t}, J=6.6, \mathrm{H}-8), 1.26-1.71(6 \mathrm{H}$, m, H-5, H-6 and H-7), 3.77-3.78 (1H, d, $J=1.6, \mathrm{H}-2), 3.96-3.97$ (1H, d, $J=2.3$, $\mathrm{H}-3), 4.55-4.59(1 \mathrm{H}, \mathrm{t}, J=6.5, \mathrm{H}-4)$.

${ }^{13} \mathrm{C}$ NMR (67.5 MHz, $\mathrm{CDCl}_{3}$ ): $\delta=13.8(\mathrm{C}-8), 22.3$ (C-7), 26.3 (C-6), 31.8 (C-5), 49.8 (C-3), $58.0(\mathrm{C}-2), 79.8(\mathrm{C}-4), 170.3(\mathrm{C}-1)$.

FI-MS: $m / z=156.1[\mathrm{M}+\mathrm{H}]^{+}$.

\section{$(2 R, 3 R)-2,3$-epoxy-4-hydroxyoctanamide $(8)$}

The diastereomeric mixture of $7(14.2 \mathrm{mg}, 91.0 \mu \mathrm{mol})$ was dissolved in a

\begin{tabular}{|c|c|c|c|c|c|c|}
\hline \multirow[t]{2}{*}{ Position } & \multicolumn{2}{|r|}{$1 a$} & \multicolumn{2}{|c|}{$1 b$ (major) } & \multicolumn{2}{|c|}{$1 c$ (minor) } \\
\hline & $\delta_{C}$, Type & $\delta_{H}(J$ in $H z)$ & $\delta_{C}$, Type & $\delta_{H}(J$ in $H z)$ & $\delta_{C}$, Type & $\delta_{H}(J$ in $H z)$ \\
\hline 1 & $170.5, \mathrm{~s}$ & - & $174.4, \mathrm{~s}$ & - & $172.9, \mathrm{~s}$ & - \\
\hline 2 & $55.8, \mathrm{~d}$ & $3.70, d(5.2)$ & $53.1, \mathrm{~d}$ & $3.57, \mathrm{~d}(2.6)$ & $54.3, \mathrm{~d}$ & $3.56, d(2.7)$ \\
\hline 3 & $59.4, \mathrm{~d}$ & $3.88, \mathrm{~d}(5.2)$ & $59.0, \mathrm{~d}$ & $3.80, d(2.6)$ & $58.1, \mathrm{~d}$ & $3.84, d(2.7)$ \\
\hline 4 & $205.8, \mathrm{~s}$ & - & $87.2, \mathrm{~s}$ & - & $86.8, \mathrm{~s}$ & - \\
\hline 5 & $41.0, \mathrm{t}$ & $\begin{array}{l}2.68, \text { ddd }(17.6,8.2,6.6) \\
2.56, \text { ddd }(17.6,8.1,6.5)\end{array}$ & $36.3, \mathrm{t}$ & $1.72, \mathrm{~m}$ & $38.9, \mathrm{t}$ & $1.78, \mathrm{~m}$ \\
\hline 6 & $26.1, \mathrm{t}$ & $1.55, \mathrm{~m}$ & $27.0, \mathrm{t}$ & $1.51, \mathrm{~m}$ & $25.9, \mathrm{t}$ & $1.41, \mathrm{~m}$ \\
\hline 7 & $23.2, \mathrm{t}$ & 1.31, sext $(7.4)$ & $24.0, t$ & 1.37, sext (7.4) & $23.9, \mathrm{t}$ & 1.38 , sext (7.4) \\
\hline 8 & $14.1, \mathrm{q}$ & $0.90, \mathrm{t}(7.4)$ & $14.3, \mathrm{q}$ & $0.94, \mathrm{t}(7.4)$ & $14.3, \mathrm{q}$ & $0.94, \mathrm{t}(7.4)$ \\
\hline
\end{tabular}
solution of $\mathrm{NH}_{3}$ in $\mathrm{MeOH}(2.0 \mathrm{M}, 3 \mathrm{ml})$ under nitrogen atmosphere and the mixture was stirred for $2.5 \mathrm{~h}$ at $0{ }^{\circ} \mathrm{C}$. The resulting solution was concentrated in vacuo and purified by silica gel column chromatography $\left(\mathrm{MeOH} / \mathrm{CHCl}_{3}=\right.$

Table $1{ }^{1} \mathrm{H}$ and ${ }^{13} \mathrm{C}$ NMR data of (+)-epogymnolactam in $\mathrm{CD}_{3} \mathrm{OD}\left(500 \mathrm{MHz}\right.$ for ${ }^{1} \mathrm{H}$ and $126 \mathrm{MHz}$ for ${ }^{13} \mathrm{C}$, Bruker) 

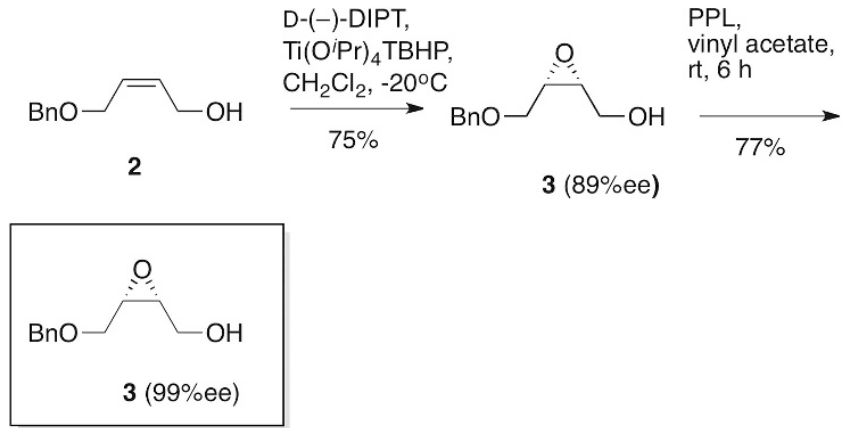

Scheme 1 A tandem strategy for preparation of enantiopure (+)-3. TBHP, tert-butyl hydroperoxide.

7:93) to afford a diastereomeric mixture of amide $8(15.1 \mathrm{mg}, 99 \%)$ as a colorless oil.

$$
[\alpha]_{\mathrm{D}}^{25}=+54.4\left(c 1.00, \mathrm{CHCl}_{3}\right)
$$

${ }^{1} \mathrm{H}$ NMR $\left(270 \mathrm{MHz}, \mathrm{CDCl}_{3}\right): \delta=0.87-0.95(3 \mathrm{H}, \mathrm{t}, J=7.1, \mathrm{H}-8), 1.32-1.69$ $(6 \mathrm{H}, \mathrm{m}, \mathrm{H}-5, \mathrm{H}-6$ and $\mathrm{H}-7), 3.07-3.21(2 \mathrm{H}, \mathrm{m}, \mathrm{H}-2$ and $\mathrm{H}-3), 3.45-3.58$ $(2 \mathrm{H}, \mathrm{m}, \mathrm{H}-4$ and $-\mathrm{OH}), 6.28\left(1 \mathrm{H}, \mathrm{s},-\mathrm{NH}_{2}\right), 6.43\left(1 \mathrm{H}, \mathrm{s},-\mathrm{NH}_{2}\right)$.

${ }^{13} \mathrm{C}$ NMR (67.5 MHz, $\left.\mathrm{CDCl}_{3}\right): \delta=14.0$ (C-8), 22.6 (C-7), 27.0 (C-6), 34.6 (C-5), 54.3 (C-2), 60.1 (C-3), 69.0 (C-4), 170.2 (C-1).

FI-MS: $m / z=174.1[\mathrm{M}+\mathrm{H}]^{+}$.

\section{(+)-Epogymnolactam (1)}

To a stirred solution of $9(7.5 \mathrm{mg}, 43.4 \mu \mathrm{mol})$ in dry $\mathrm{CH}_{2} \mathrm{Cl}_{2}(1.6 \mathrm{ml})$, DessMartin periodinane $(25.7 \mathrm{mg}, 60.6 \mu \mathrm{mol})$ was added under argon at $0{ }^{\circ} \mathrm{C}$. After stirring for $2 \mathrm{~h}$, the mixture was quenched with sat. aqueous $\mathrm{Na}_{2} \mathrm{~S}_{2} \mathrm{O}_{3}$ and sat. aqueous $\mathrm{NaHCO}_{3}$. The solution was extracted with EtOAc and the organic layer was washed with brine, dried over $\mathrm{Na}_{2} \mathrm{SO}_{4}$, concentrated in vacuo and purified by silica gel column chromatography $(\mathrm{EtOAc} /$ hexane $=2: 1)$ to afford (+)-epogymnolactam (1) (5.6 mg, 76\%) as a yellow solid.

$$
[\alpha]_{\mathrm{D}}^{25}=+25.6(\text { c } 0.49, \mathrm{MeOH})
$$

${ }^{1} \mathrm{H}$ and ${ }^{13} \mathrm{C}$ NMR: see Table 1 .

HR-ESI-MS: $m / z=194.07876[\mathrm{M}+\mathrm{Na}]^{+}$calcd. for $\mathrm{C}_{8} \mathrm{H}_{13} \mathrm{O}_{3} \mathrm{NNa}$, found 194.07887.

\section{RESULTS AND DISCUSSION}

Among the total syntheses of (+)-cerulenin, the concise synthesis by Townsend group ${ }^{17}$ seemed to be most effective. Optically pure $(+)$-cerulenin was synthesized with use of the coupling reaction of a chiral oxiranyllithium with a side-chain aldehyde as a key step. (+)-Epogymnolactam (1) would be synthesized in 10 steps starting from propargyl alcohol, and the number of reaction steps in the synthetic route was shorter than any other known synthetic methods from glucose, ${ }^{18,19}$ tartaric acid ${ }^{20}$ or a four-carbon synthon obtained by Sharpless epoxidation. ${ }^{21}$ We decided, however, to develop the straightforward synthesis of $(+)-\mathbf{1}$, which could be achieved in fewer steps by using the enantiomer of Sudalai's epoxy alcohol ( $96 \%$ ee, as TBS-alternate of $(-)-3)^{22}$ synthesized via Sharpless asymmetric epoxidation using $(+)$-DET as a chiral source. Nevertheless, we could not reproduce such a high enantioselectivity in the synthesis of TBS alternate of (+)-3 using ( - )-DET. In general, Sharpless epoxidation of cis allylic alcohol has been shown not to give high enantiomeric excess especially in the large-scale preparation in a reproducible manner. Sharpless epoxidation of cis-4-benzyloxy-2-buten-1-ol 2 resulted in $89 \%$ ee similar to the observation by Terashima group. ${ }^{23}$ We tried to obtain enantiopure (+)-3 by a recrystallization of 3,5-dinitrobenzoate of 3 followed by alkaline hydrolysis, ${ }^{24}$ whereas we could not obtained an acceptable result, and abandoned optimization of this procedure,
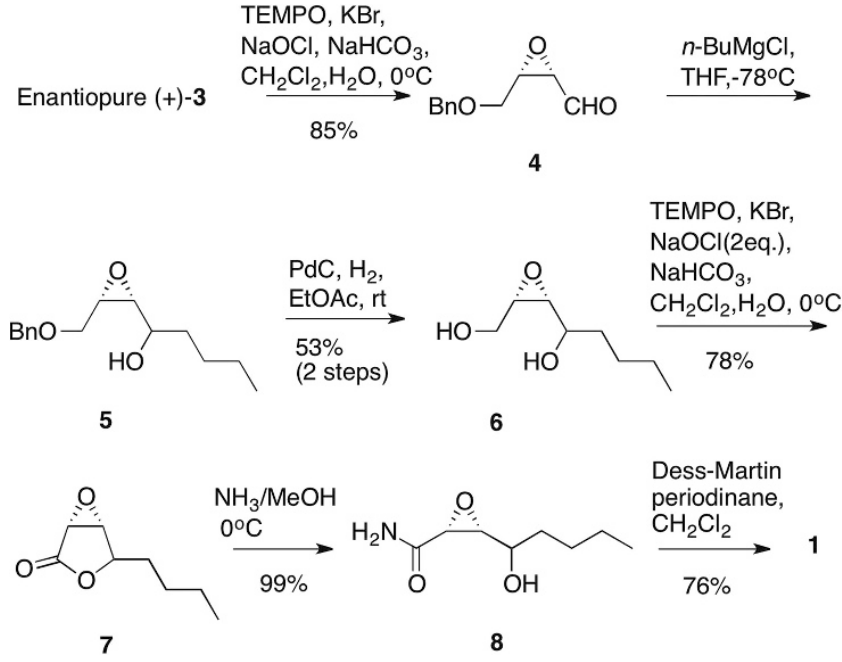

Scheme 2 Total synthesis of (+)-epogymnolactam (1). THF, tetrehydrofuran.

because a three-step process involving dinitrobenzoylation, recrystallization and hydrolysis was needed in any case.

Next we searched for the best conditions to obtain enantiopure (+)-3 by a lipase-mediated kinetic resolution of the corresponding acetate prepared by acetylation of 3 ( $89 \%$ ee). Epoxy alcohol (+)-3 could be obtained with up to $96 \%$ ee by hydrolysis of the acetylated precursor with PPL, unfortunately this procedure did not give reproducible results and gave mostly unsatisfactory enantioselectivity less than $90 \%$ ee. ${ }^{25}$

Finally, we devised the most reliable procedure to prepare enantiopure (+)-3 (99-100\% ee) by treating 3 ( $89 \%$ ee) with PPL in vinyl acetate $^{26}$ as shown in Scheme 1. This type of tandem strategy for preparation of epoxy alcohols could be generally useful because Sharpless epoxidation has been applied for tremendous number of allylic alcohol but it was difficult to obtain epoxy alcohol having nearly $100 \%$ ee. We believe this tandem strategy, Sharpless epoxidation/lipase kinetic resolution for preparation of enantiopure epoxy alcohol becomes one of the standard methods in organic synthesis.

The first total synthesis of (+)-1 was achieved in a straightforward route outlined in Scheme 2. Dess-Martin oxidation ${ }^{27}$ of 3 afforded aldehyde 4 in $91 \%$ yield. Large-scale preparation of 4 was done by costeffective TEMPO oxidation ${ }^{28}$ whose yield was $85 \%$. Grignard reaction of 4 with $n$ - $\mathrm{BuMgCl}$ in $\mathrm{THF}$ at $-78^{\circ} \mathrm{C}$ followed by deprotection of benzyl group of $\mathbf{5}$ with hydrogen and palladium/carbon catalyst in EtOAc at RT gave desired epoxy diol 6 in 53\% yield over two steps. TEMPO oxidation of 6 in the presence of 2.2 eq. of $\mathrm{NaOCl}^{29}$ at $0{ }^{\circ} \mathrm{C}$ provided epoxy lactone 7 in $78 \%$ yield. Two diastereomers could be separated by silica gel column chromatography $($ EtOAc/hexane $=1: 4)$. Ammonolysis of 7 with $\mathrm{NH}_{3}$ in $\mathrm{MeOH}$ at $0{ }^{\circ} \mathrm{C}$ furnished desired amide alcohol 8 in 99\% yield. All synthetic intermediates 5, 6, 7 and 8 existed as a mixture of two diastereomers, whereas no inconvenience in the structure determinations of these intermediates by NMR analysis. Oxidation of the both two diastereomeric alcohols should primarily generate the open-chain form 1a. The amide alcohol 8 was successfully converted into (+)-1 by Dess-Martin periodinane in $\mathrm{CH}_{2} \mathrm{Cl}_{2}$ at $\mathrm{RT}$ in $76 \%$ yield. Analyses of ${ }^{1} \mathrm{H}$ and ${ }^{13} \mathrm{C}$ NMR showed that synthetic (+)-1 existed as a ring-chain tautomeric mixture of ketoamide (1a) and diastereomeric hydroxy lactams $(\mathbf{1 b}$ and $\mathbf{1 c})$ in $\mathrm{CD}_{3} \mathrm{OD}$ as in the case of natural (+)-1. The physicochemical properties and autophagy-inducing activity of synthetic (+)-1 were consistent with those of natural epogymnolactam. Therefore, the absolute configuration of natural epogymnolactam was unambiguously confirmed as shown in Figure 1. 
Given the enough amount of synthetic (+)-1, we first decided to clarify the ratio of three isomers, keto isomer 1a, major cyclic isomer $\mathbf{1 b}$ and minor cyclic isomer $\mathbf{1 c}$ in $\mathrm{CD}_{3} \mathrm{OD}$. A tautomeric ratio (1a:1b:1c $=4.7: 4.0: 1.3)$ of synthetic epogymnolactam (1) right after dissolving in $\mathrm{CD}_{3} \mathrm{OD}$ changed into a different ratio $(\mathbf{1} \mathbf{a}: \mathbf{1} \mathbf{b}: \mathbf{1 c}=2.5$ : 6.0: 1.5) with time. This phenomenon suggests that the keto isomer 1a is most stable in the absence of solvent. The complete NMR assignments of $\mathbf{1 a}, \mathbf{1} \mathbf{b}$ and $\mathbf{1 c}$ are shown in Table 1.

In conclusion, we accomplished the first total synthesis of $(+)$-epogymnolactam (1), and determined the absolute configuration of 1 unambiguously.

\section{ACKNOWLEDGEMENTS}

This work was supported by a grant from the Institute for Fermentation, Osaka (IFO), Japan, and a Grant-in-Aid for Scientific Research (C) (No. 26450135) from the Japan Society for the Promotion of Science (JSPS). We are grateful to Dr E Fukushi (Graduate School of Agriculture, Hokkaido University) for NMR measurements of synthetic (+)-epogymnolactam.

1 Mitsuhashi, S., Shindo, C., Shigetomi, K., Miyamoto, T. \& Ubukata, M. (+)-Epogymnolactam, a novel autophagy inducer from mycelial culture of Gymnopus sp. Phytochemistry 114, 155-159 (2015).

2 Cuervo, A. M. Autophagy: in sickness and in health. Trends Cell Biol. 14, 70-77 (2004).

3 Nixon, R. A. \& Yang, D.-S. Autophagy failure in Alzheimer's disease-location the primary defect. Neurobiol. Dis. 43, 38-45 (2011).

4 Jimenez, R. E., Kubli, D. A. \& Gustafsson, Å. B. Autophagy and mitophagy in the myocardium: therapeutic potential and concerns. Br. J. Pharmacol. 171, 1907-1916 (2014).

5 Rubinsztein, D. C., Codogno, P. \& Levine, B. Autophagy modulation as a potential therapeutic target for diverse diseases. Nat. Rev. Drug Discov. 11, 709-730 (2012)

6 Shoji-Kawata, S. et al. Identification of a candidate therapeutic autophagy-inducing peptide. Nature 494, 201-206 (2013).

7 Ravikumar, B. et al. Inhibition of mTOR induces autophagy and reduces toxicity of polyglutamine expansions in fly and mouse models of Huntington disease. Nat. Genet. 36, 585-595 (2004).

8 Sarkar, S. et al. Lithium induces autophagy by inhibiting inositol monophosphatase J. Cell. Biol. 170, 1101-1111 (2005).

9 Williams, A. et al. Novel targets for Huntington's disease in an mTOR-independent autophagy pathway. Nat. Chem. Biol. 4, 295-305 (2008)
10 Jeong, J. K. et al. Autophagy induced by resveratrol prevents human prion proteinmediated neurotoxicity. Neurosci. Res. 73, 99-105 (2012).

11 Gupta, V. K. et al. Restoring polyamines protects from age-induced memory impairment in an autophagy-dependent manner. Nat. Neurosci. 16, 1453-1460 (2013).

12 Chin, R. M. et al. The metabolite a-ketoglutarate extends lifespan by inhibiting ATP synthase and TOR. Nature 510, 397-401 (2014).

13 D'Agnolo, G., Rosenfeld, I. S., Awaya, J., Omura, S. \& Vagelos, P. R. Inhibition of fatty acid synthesis by the antibiotic cerulenin. Specific inactivation of beta-ketoacyl-acyl carrier protein synthetase. Biochim. Biophys. Acta. 326 155-156 (1973).

14 Sano, Y., Nomura, S., Kamio, Y., Omura, S. \& Hata, H. Studies on cerulenin, 3. Isolation and physico-chemical properties of cerulenin. J. Antibiot. 20, 344-348 (1967)

15 Funabashi, H. et al. Binding site of cerulenin in fatty acid synthetase. J. Biochem. 105, 751-755 (1989).

16 Kuhajda, F. P. et al. Fatty acid synthesis: a potential selective target for antineoplastic therapy. Proc. Natl Acad. Sci. USA 91, 6379-6383 (1994).

17 Mani, N. S. \& Townsend, C. A. A concise synthesis of (+)-cerulenin from a chira oxiranyllithium. J. Org. Chem. 62, 636-640 (1997).

18 Sueda, N., Ohrui, H. \& Kuzuhara, H. Stereoselective synthesis of (+)-cerulenin from D-glucose. Tetrahedron Lett. 20, 2039-2042 (1979).

19 Pietraszkiewics, M. \& Sinaÿ, P. Total synthesis of natural cerulenin from D-glucose. Tetrahedron Lett. 20, 4741-4744 (1979).

20 Yoda, H., Katagiri, T. \& Takabe, K. A novel stereoselective synthesis of (+)-cerulenin and (+)-tetrahydrocerulenin. Tetrahedron Lett. 32, 6771-6774 (1991).

21 Furukawa, J., Funabashi, H., Morisaki, N., Iwasaki, S. \& Okuda, S. A new versatile synthesis of cerulenin. Chem. Pharm. Bull. 36, 1229-1232 (1988).

22 Rawat, V., Dey, S. \& Sudalai, A. Synthesis of the anti-influenza agent (-)-oseltamivir free base and (-)-methyl 3-epi-shikimate. Org. Biomol. Chem. 10, 3988-3990 (2012).

23 Yoshino, T. et al. Total synthesis of an enantiomeric pair of FR900482. 2. Synthesis of the aromatic and the optically active aliphatic segments. Tetrahedron 53, 10239-10252 (1997)

24 Mori, K. \& Seu, Y.-B. A new synthesis of (-)-a-multistriatin, the pheromone of the smaller European elm bark beetle. Tetrahedron 44, 1035-1038 (1988).

25 Faigl, F. et al. Efficient, scalable kinetic resolution of cis-4-benzyloxy-2,3-epoxybutanol. Tetrahedron Asymmetry 16, 3841-3847 (2005).

26 Shen, L.-L., Wang, F., Mun, H.-S., Suh, M. \& Jeong, J.-H. Solvent-dependent reactivity in porcine pancreatic lipase (PPL)-catalyzed hydrolysis. Tetrahedron Asymmetry 19, 1647-1653 (2008)

27 Dess, D. B. \& Martin, J. C. A useful 12-I-5 triacetoxyperiodinane (the Dess-Martin periodinane) for the selective oxidation of primary or secondary alcohols and a variety of related 12-I-5 species. J. Am. Chem. Soc. 113, 7277-7287 (1991).

28 Nakashima, T., Baba, T., Onoue, H., Yamashita, W. \& Torikai, K. A facile and practical synthesis of Nicolauo's key intermediates, 2-methyl- and 2,6-dimethyltetrahydropyrans, toward the total synthesis of ladder-shaped polyethers. Synthesis 45 , 2417-2425 (2013).

29 Yadav, R. N., Mondal, S. \& Ghosh, S. An efficient stereoselective route to the construction of tricyclic core structure towards the synthesis of the sesquiterpens of the seco-prezizaane family. Tetrahedron Lett. 52, 1942-1945 (2011). 